\title{
FIATALOK BORISMERETI ATTITÜDJE ÉS AZ ISMERETSZERZÉS AKADÁLYMENTES GYAKORLATA A GARAY ÉLMÉNYPINCÉBEN
}

\author{
${ }^{1}$ Dr. Slezák-Bartos Zsuzsanna $-{ }^{2}$ Dr. Máté Andrea $-{ }^{3}$ Guld Zsuzsanna \\ ${ }^{1}$ Pécsi Tudományegyetem Kultúratudományi, Pedagógusképző és Vidékfejlesztési Kar \\ slezak-bartos.zsuzsanna@pte.hu \\ ${ }^{2}$ Pécsi Tudományegyetem Kultúratudományi, Pedagógusképzö és Vidékfejlesztési Kar \\ mate.andrea@pte.hu; \\ ${ }^{3}$ Pécsi Tudományegyetem Kultúratudományi, Pedagógusképző és Vidékfejlesztési Kar \\ vas-guld.zsuzsanna@pte.hu
}

DOI: $10.15170 /$ TVT.2021.06.01.04

\begin{abstract}
Absztrakt
A fiatalok egyre inkább érdeklődnek a borfogyasztás iránt, amely köszönhető a hazai borászat sikerének illetve a bor- és gasztronómiai rendezvények népszerüségének. Azonban fontos, hogy ez a növekvő érdeklődés tudatos, kulturált borfogyasztással párosuljon. Ennek a szemléletmódnak a terjesztésében és a borkultúra megismertetésében a felsőoktatásnak meghatározó szerepe van, hiszen tudatos, kontrollált keretek között tudja biztosítani a borfogyasztási ismeretek elsajátítását. Tehát a felsőoktatásban megjelenő hallgatók a kulturált borfogyasztás potenciális piaca, ezért kiemelten fontos a fiatal felnőttek borfogyasztási és borvásárlási szokásainak vizsgálata. A Pécsi Tudományegyetem példája jól igazolja, hogy a borvidékekhez való földrajzi közelség, a Pannon borrégió borászatainak sikere, változatos borturisztikai kínálata pozitív kötödést alakít ki az egyetem hallgatóiban. Hiszen a megkérdezett hallgatóink többsége szívesen fogyaszt bort, elsősorban a rozét és a vörösbort kedvelik. Leginkább a Villányi és Szekszárdi borvidék borai iránt érdeklődnek. Viszont kevésbé ismert számukra a gyöngyözőbor vagy a siller, pedig a borrégió ezt is kínálja. Bár föként az édes és félédes bort szeretik, mégis a vörösboros kóla helyett népszerübb lett a fröccsfogyasztás. Vagyis a fiatalok ízlése fejlödik és alakítható, nyitottak az újdonságra.

Tanulmányunkban a Pécsi Tudományegyetem 369 hallgatója körében végzett szőlészet-borászat trendkutatás további eredményeit ismertetjük. A rozé bor és a fröccs fogyasztásának divatossá válásával a fiatalok körében a legkedveltebb alkoholos ital a bor lett. A régióban található számos borvidék és a hozzájuk kapcsolódó bormarketing és borturisztikai rendezvény hatására közelebb kerültek a fiatalok a borok világához. Ebben a folyamatban jelentős szerepet töltenek be a Pannon borrégió borkultúrát és borfogyasztást népszerüsítő innovatív szervezetei, mint a borúti egyesületek, a borturisztikai klaszter vagy a borrendek. Tanulmányunk második részében a fiatalok borvásárlási szokásaira, költési magatartására, valamint a borral kapcsolatos ismeretek bővítési hajlandóságára térünk ki. A borfogyasztási szokások elemzése kapcsán kiemelt figyelmet fordítottunk a keresleti trendekre illetve a Pannon Borrégióban meghatározott célcsoportok vizsgálatára fókuszáltunk. A hallgatók a Villányi és a Szekszárdi borvidéket kedvelik a legjobban. Vásárlási döntés esetén saját borfogyasztásnál az ár (77,5\%), míg ajándékozás esetén a minőség $(82 \%)$ a legmeghatározóbb. A borokkal kapcsolatos információk jelentős részét barátoktól, rokonoktól, illetve közösségi oldalakról szerzik be. A megkérdezettek $84 \%$-a szívesen részt venne borral kapcsolatos képzéseken.
\end{abstract}


Az akadálymenetes lehetőségek Szekszárdon a Garay Élménypincében érhetőek el, amely olyan méretü, jellegü és színvonalú bemutatóterem, ami egyedülálló Magyarországon. Akár több csoport egyidejü befogadására is képes, lehetőséget kínálva magyar vagy külföldi érdeklődőknek. Az interaktív kiállítást még értékesebbé teszi, hogy a borkedvelők több nyelven is kaphatnak információt szekszárdi borokról, szekszárdi borászokról, a borkóstolás rejtelmeiről, borkultúráról, borgasztronómiáról.

Kulcsszavak: akadálymentes borfogyasztás, kulturált borfogyasztás, borkultúra, borvásárlási szokások, Pannon Borrégió

\begin{abstract}
Youth shows an increased interest in wine consumption, which is due to the success of the Hungarian wine sector and also to the popularity of wine- and gastronomy-related events in Hungary. It is important though that this increased interest should be matched with conscious and civilised wine consumption. Higher education has an outstanding role in disseminating this attitude and the spread on information on wine consumption culture, as it can promote the acquisition of civilised wine consumption skills within conscious and controlled frameworks. In other words: students of higher education are a potential market for civilised wine consumption, which makes the research and survey of the wine consumption and purchasing habits of young adults especially important.
\end{abstract}

Our paper is a summary of the findings of a viticulture and wine sector trend research done with the students of the University of Pécs. The example of the University of Pécs shows that the geographical proximity to the wine producing areas of the Pannonian Wine Region, the achievements and the diverse enological tourism supply of the wineries of the wine region have created a positive attachment in the students of the university. Most of the students questioned have a high propensity to consume wine; especially rosé and red wines are popular. The wines most favoured by them are from the Villány and the Szekszárd wine producing areas. However, they have limited knowledge about sparkling wine and schiller, despite that fact that these are also part of the supply of the wine region. Although their favourites are sweet and semi-sweet wines, still the consumption of spritzer now exceeds that of Kalimocho (red wine and coke).

Our paper also deals with the wine purchasing habits of the youth, and their willingness to expand their knowledge about wines. When making a decision on purchase, for own consumption it is price $(77.5 \%)$, in the case of presenting the wine to someone else it is quality $(82 \%)$ that is the dominant factor. A significant part of the wine-related information is gained from friends, relatives and from social media. The majority of the respondents (84\%) are happy to participate in trainings on wine.

This shows that the taste of the youth is developing and can be influenced; young people are open to novelties. In this process, a significant role is played by innovative organisations promoting wine culture and wine consumption in the Pannonian Wine Region: wine route associations, enological tourism cluster or the wine orders.

The accessible opportunities are available in the Garay Experience Cellar in Szekszárd, which is a showroom of a size, character and quality that is unique in Hungary. It can even accommodate several groups at the same time, be it Hungarian or foreign interested parties. What makes the interactive exhibition even more valuable is that wine lovers can receive information about Szekszárd wines, Szekszárd winemakers, the mysteries of wine tasting, wine culture and wine gastronomy in several languages.

Keywords: accessible wine consumption, civilised wine consumption, wine culture, wine purchasing habits, Pannonian Wine Region 


\section{Bevezetés}

Napjainkban a különböző borászati és gasztronómiai trendek hatására egyre több figyelem fordul a tudatos, kulturált borfogyasztásra, amelynek egyik szegmensét képezik azok a fiatal felnőttek, akik egyre inkább érdeklődnek a borkultúra iránt. E jövőbeli potenciális vásárlóközönség tulajdonságainak, hozzáállásának és fogyasztási szokásaiknak az ismerete különösen fontos, mind a bormarketing, mind pedig a hazai borturizmus fejlesztése szempontjából. Tanulmányunkban a Pécsi Tudományegyetem hallgatói körében végzett trendkutatás eredményeit ismertetjük, amely kutatást a TÁMOP-4.2.1.d-15/1/KONV-2015-0001 számú „Társadalmi innováció és hálózatépítés a Pécsi Tudományegyetem tudásbázisán a Dél-Dunántúli Régióban" címü pályázat támogatásával valósítottuk meg. A kutatás célja az volt, hogy releváns képet kapjunk a fiatal felnőttek körében elterjedt borfogyasztási és borvásárlói szokásokról, a borismereti tudásukról. (MÁTÉ et al. 2015) A fogyatékossággal élő emberek igénye folyamatosan növekszik a turizmusban való részvételre. Az elérhető turizmus kínálata, a Magyarországon elérhető szolgáltatások szükítik lehetőségeiket. (ANGLER 2020) Bemutatásra kerül tanulmányunkban a borturisztikai szempontból is jelentős szolgáltatásokat kínáló Garay Élménypince, mely az akadálymentes turizmust támogatja. Fontos szempontént jelenítjük meg kutatásunkban az ismeretszerzés akadálymentesítését, hiszen ismeret nélkül nincs kulturált borfogyasztás. A pandémia időszakában az online borkóstolókkal egy újabb akadálymentes megoldást kínálnak az élményekhez és az ismeretszerzéshez.

\section{Elméleti háttér}

\subsection{Borfogyasztási szokások vizsgálata hazánkban}

A borfogyasztási és borvásárlási szokások vizsgálata Nyugat-Európában több évtizedes múltra tekint vissza. Azonban hazánkban csak az ezredforduló környékén jelentek meg az első komolyabb kutatási eredmények a magyar borfogyasztási szokásokról. Napjainkban egyre nagyobb figyelmet kap a téma, hiszen a borászati és gasztronómiai trendek változása (például technológiai újítások, marketing innovációk) nemcsak a termelést, elöállítást korszerüsítik, hanem új divatot teremtenek, és ezáltal a fogyasztási szokásokat is befolyásolják. A borfogyasztók szokásainak, elvárásainak ismerete egyre fontosabb az erősödő piaci versenyben, hiszen új fejlődési irányokat határozhat meg, amely az egész ágazat hosszú távú, bel- és külpiaci alakulására is hatással lehet. HOFMEISTER TÓTH és TOTTH (2002) kutatásukban az értékek szerepét vizsgálták a borválasztásban. Az FVM Agrármarketing Centrum Kht. megbízásából 2003-ban az OSZKÖ Tanácsadó Bt. és az FVM Kecskeméti Szőlészeti és Borászati Kutatóintézete végezte el a borfogyasztási szokások vizsgálatát Magyarországon. Ennek eredményeképpen öt piaci célcsoportot alakítottak ki: a borbarát, a gourmet, a középkategóriát kereső, az ajándékozó, az absztinens szegmensét. (OSZOLI et al. 2003) Ezek az eredmények jelennek meg a HAJDU ISTVÁNNÉ $(2004,2005)$ által szerkesztett Bormarketing és Borpiac szakkönyvekben is. A Magyar Turizmus Rt. megbízásából készítette el a M.Á.S.T. Piac- és Közvéleménykutató Társaság 2005-ben a magyar lakosság étkezési és alkoholfogyasztási szokásainak és Magyarország gasztronómiai imázsának vizsgálatát. A komplex kutatás a 2006-ban meghirdetett Bor és Gasztronómia tematikus év turizmus marketing tevékenységének elökészítése miatt vált szükségessé. (MTRt. - M.Á.S.T. 2006) A rövid ideig müködő Magyar Bormarketing Kht. 2008ban nemcsak a fogyasztási szokások felmérését végezte, hanem elkészítette a Közösségi Bormarketing Stratégiát is. A szakmai anyag a kiemelt piaci szegmensek mellett javaslatokat tett a 2009-2013 közötti marketing tevékenységekre is. A stratégiában az ínyenc, az igényes, a hétköznapi fogyasztó, valamint az absztinens és a „borkerülök” célcsoportokat határozták meg. (ALPÁR et al. 2008) A szakmaközi szervezet megszünésével a közösségi bormarketing helyzete jelentősen megrendült, amelyet nem tud kompenzálni, hogy az Agrármarketing Centrum a Magyar Turizmus Zrt. felügyelete alá került. 
Pályázati forrásoknak köszönhetően 2008-2009 között elkészülhetett a Pannon Borrégió Bormarketing Stratégiája. (1. ábra) Már ekkor is megmutatkozott, hogy a borrégióban a borturizmusnak és a hozzá kapcsolódó fogyasztásnak meghatározó szerepe van a borpiacon. A borrégióban végzett piacfeltárás alapján a borvásárlás és a borturizmus kiemelt célcsoportjai: a fiatal felnőttek, a nők, a borbarátok, a szakmai közönség, a borturisztikai, borgasztronómiai szakképzések résztvevői, a borászati, borgasztronómia programok és borúti szolgáltatások iránt érdeklődők, a Pannon borrégió lakossága, a budapesti bor iránt érdeklődő közönség lett. (GONDA — KOVÁCS 2014, MÁTÉ - SZABÓ 2011)

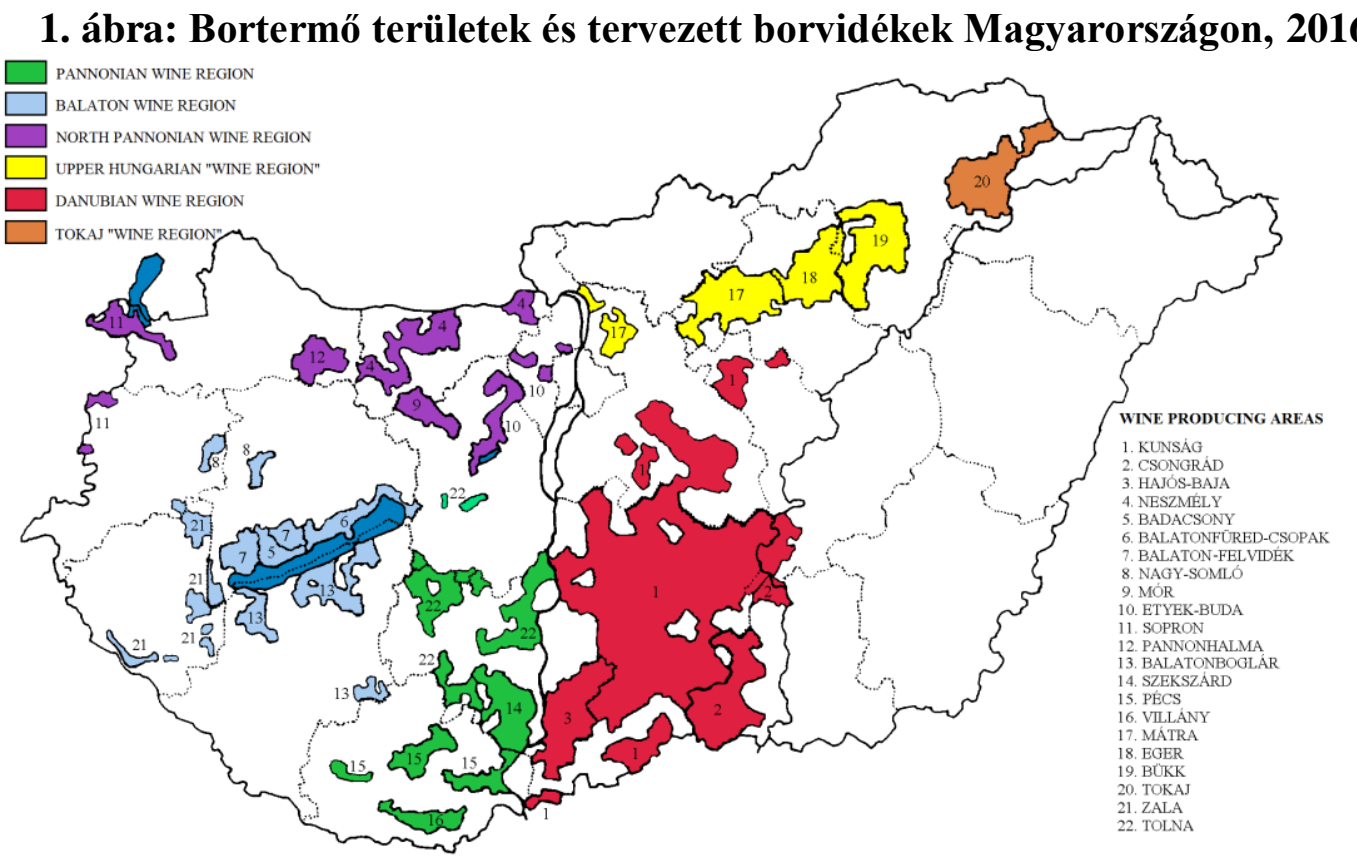

Forrás: Máté A. www.hnt.hu alapján

A soproni Bormarketing Mühely Nonprofit Kft. szervezésében 2000 és 2013 között évente megrendezett Magyarországi Bormarketing Konferencia fontos helyszíne volt a hazai borfogyasztási és borvásárlási szokások vizsgálati eredményeinek megismertetésében. A Magyar Turizmus Zrt. Agrármarketing Centrum megbízásából a Bormarketing Műhely 2013- ban kutatást végzett, amelynek fókuszában a borvásárlók igényeinek, véleményének, preferenciáinak megismerése állt. (Bormarketing Mühely Nonprofit Kft. 2013)

\subsection{Kutatási módszerek}

A Pécsi Tudományegyetem hallgatói körében online kérdöíves felmérést végeztünk a borfogyasztási és borvásárlási szokásaik megismerése érdekében. A megkérdezés véletlenszerüen történt. A válaszadás önkéntes és anonim volt, a lekérdezés 2015.09.14.-2015.10.07. időszakban történt. Az alapsokaságot a teljes hallgatói létszám jelentette. 2015-ben a PTE-n 17023 fö magyar hallgató szerepelt a nyilvántartásokban, tehát az összlétszám 2,16\%-a került lekérdezésre. A statisztikai feldolgozás érdekében a kérdéstípusok többsége (elöre meghatározott válaszokat tartalmazó) zárt kérdés, valamint értékelési skálába (1-től 5-ig számmal) sorolt válaszokat tartalmazó kérdés volt. A feldolgozás során az Excel adatbázis alapján összesítő, arányokat, értékátlagokat bemutató kör- és oszlopdiagramok készültek. A kérdőíves kutatásban három témakört emeltünk ki: a borfogyasztási és a borvásárlási szokásokat, valamint a borral kapcsolatos ismereteiket, és azok bővítésének hajlandóságát. A tanulmányunkban egyrészt áttekintjük, hogy a fiatalok milyen típusú, fajtájú, alkalmanként mekkora mennyiségü bort fogyasztanak, mely borvidékeket kedvelik, milyen borfogyasztási attitüd jellemzi őket. 
Másrészt pedig feltárjuk az olvasó számára, hogy a hallgatók milyen szempontok alapján és hol vásárolnak bort, mennyit hajlandóak költeni egy palack borra, honnan szereznek információkat a borokról, valamint hajlandóak-e ismereteik bővítésére. A kérdőíves kutatásba 369 hallgatót vontunk be. A válaszadók egyharmada férfi $(34,7 \%)$, kétharmada nő $(65,3 \%)$ volt. A megkérdezett hallgatók többsége $(91,1 \%)$ a fiatal korosztályból (18-29 év) került ki, a megkérdezetteknek mindössze 8,9\%-a tartozott a középkorosztályhoz (30-59 év). A hallgatók háromnegyedének (73,7\%) középiskolai végzettsége volt, akik ekkor folytatták az első felsőoktatási tanulmányaikat felsőoktatási szakképzésen (FOKSZ) vagy alapképzésen (BA/BSc), míg egynegyedük már rendelkezett alapdiplomával $(24,7 \%)$, tehát ők további mesterképzésen (MA/MSc), szakirányú továbbképzésen vagy doktori képzésen $(\mathrm{PhD})$ vettek részt az egyetemen. (2. ábra) A konkrét szakokra nem történt további szegmentálás, 2015-ben szőlész-borász képzés még nem folyt az egyetemen, mely a nagyobb tudásanyaggal, ismeretekkel rendelkező hallgatói csoport vizsgálatát indokolta volna.

\section{2. ábra: A megkérdezettek hallgatók szak és tagozat szerinti megoszlása}

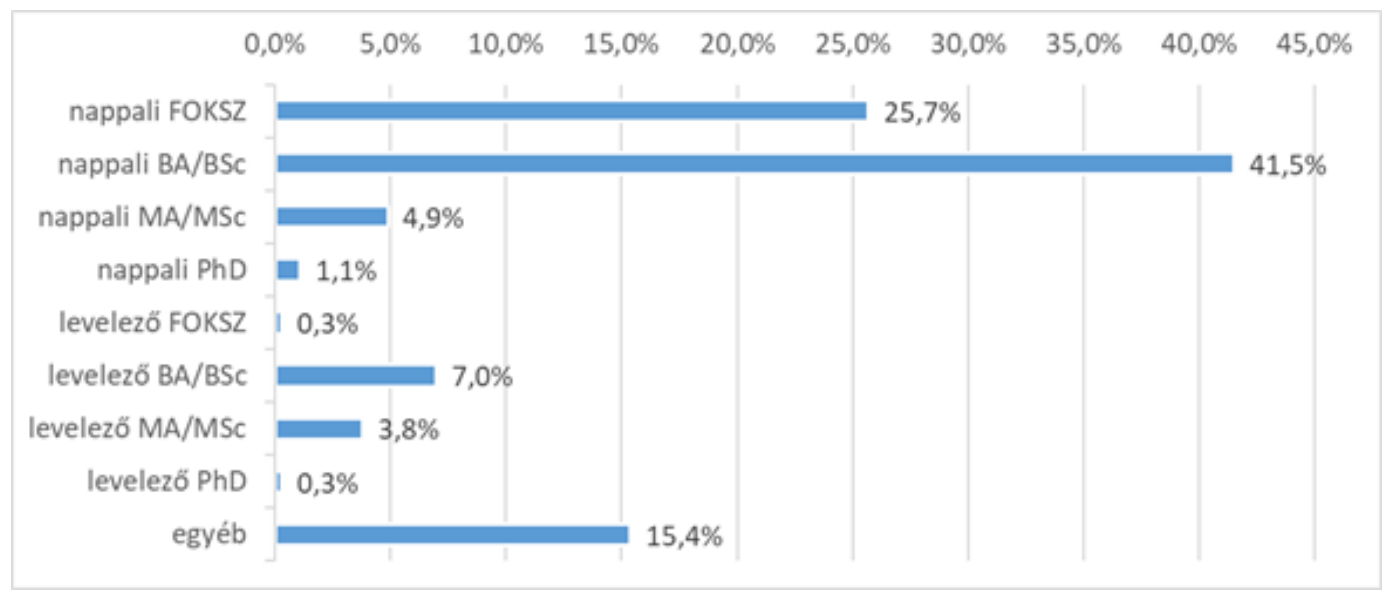

Forrás: Máté A.

A válaszadók kétharmada Baranya és Tolna megyéből származott, amely jól tükrözi az egyetem vonzáskörzetét. A legtöbb választ a Baranya megyeiektől (43,1\%), majd a Tolna megyeiektől $(23,3 \%)$ kaptuk. Harmadik helyre a Pest megyeiek $(9,2 \%$, többségében budapestiek) kerültek. A Somogy (6,5\%), a Bács-Kiskun (4,9\%) és a Fejér (3,0\%) megyei hallgatók válaszadása volt még számottevőbb. A hallgatók egytizede a többi megyéböl került ki (0-1,6\% közötti arányban).

\section{Eredmények}

2.1. Borfogyasztási szokások vizsgálatának eredményei a Pécsi Tudományegyetem hallgatói körében

A hallgatók válaszaiból megállapítható, hogy az általunk említett alkoholtípusok (3. ábra) közül a bor $(3,86)$ a legnépszerübb és a pálinka $(2,84)$ a legkevésbé kedvelt. A válaszadók 40\%-a nagyon kedveli a bort, és mindössze $6 \%$ az, aki egyáltalán nem kedveli. 


\section{3. ábra: Az alkohol tartalmú italok kedveltsége}

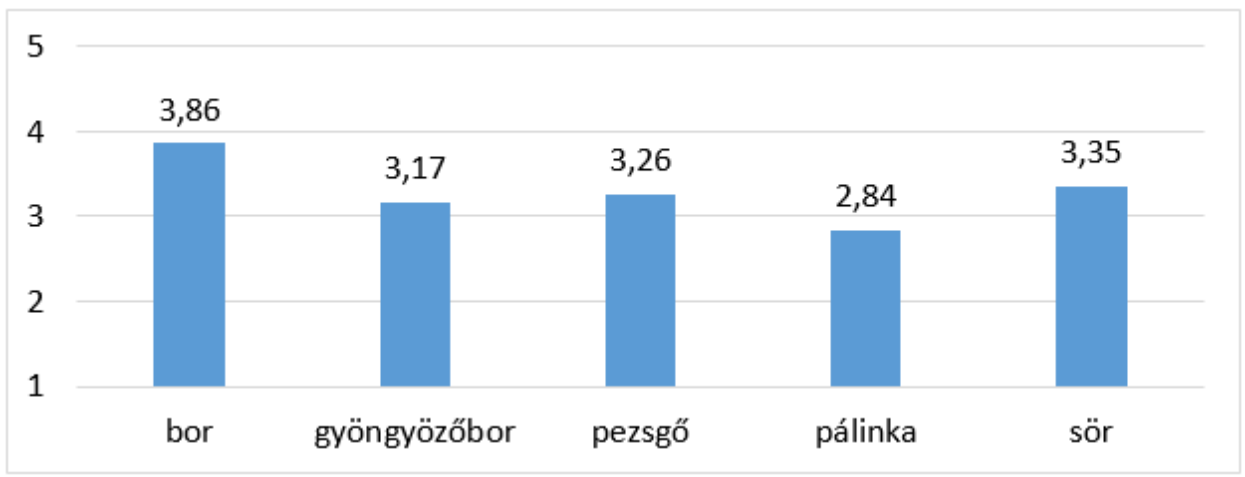

Forrás: Máté A.

Megjegyzés: ,, 1 ” az egyáltalán nem kedveli és ,,5” a nagyon kedveli kategóriát jelenti

A bor után kedveltségben a sör $(3,35)$, a pezsgö $(3,26)$, majd a gyöngyöző bor $(3,17)$ következett, amelyek átlagértéke között nincs jelentős különbség. A megkérdezettek 31\%-a a sört, 24\%-a a pezsgöt és 11\%-a gyöngyöző bort kedveli leginkább. A gyöngyöző bor esetében a hallgatók 19\%a nem tudott válaszolni a kérdésre, míg a többi alkoholnál ez az arány $1 \%$ alatti érték volt, vagyis a megkérdezettek csaknem egyötöde nem tudja mit jelent a gyöngyöző bor. A válaszadóknak csak a 19\%-a kedveli nagyon a pálinkát és $26 \%$ pedig egyáltalán nem, vagyis a pálinka megítélése nem kedvező a fiatalok körében. (3. ábra)

A megkérdezettek kicsivel több, mint egyharmada $(36,6 \%)$ hetente fogyaszt bort, a másik harmad $(32,2 \%)$ azonban már csak havonta fogyasztja. A hallgatók csaknem egynegyede $(23,8 \%)$ a havinál ritkábban iszik bort. Mindössze 3,3\% fogyaszt naponta bort. A megkérdezettek körében igen alacsony az antialkoholisták aránya, alig 4\%. Tehát a fiatalok többsége (96\%) szívesen fogyaszt bort. A válaszadóknak mindössze 4\%-a az, aki soha nem fogyaszt bort. Ennek oka elsősorban, hogy nem szeretik a bor ízét, szagát (40\%), vagy az illetö antialkoholista, ami miatt soha nem fogyaszt alkoholt (33\%). Minimális azok aránya (7- 7\%) akik egészségügyi vagy családi okokból nem fogyasztanak bort. A borfogyasztók 40,2\% alkalmanként 3-5 dl közötti mennyiséget fogyaszt. A válaszadók harmada $(29,1 \%)$ alkalmanként $1-2$ dl bort, míg egytizede $(9,1 \%)$ alig fél dl-t fogyaszt. A megkérdezettek 16,5\%-a egy-egy alkalommal 6-9 dl között iszik bort. Mindössze 5,1\% iszik alkalmanként 1 liter feletti mennyiséget, ami már igencsak meghaladja az egészséges mértéket. A borfogyasztók kétharmada $(71,2 \%)$ tisztán, a fele $(49,9 \%)$ pedig szódával issza a bort. Azonban a hallgatók egyharmadánál $(29,4 \%)$ a boros kóla is népszerü, amely jellemző fogyasztási mód ennél a korosztálynál. A válaszadók 3,7\%-a egyéb módon (pl.: almalével, szőlőlével, Sprite üdítővel) fogyasztja a bort. Az emberek borfogyasztási kedve függ egy adott helyzettől, helyszíntől vagy társaságtól. A megkérdezett közül senki nem fogyaszt otthon, társaság nélkül bort. (4. ábra) 


\section{4. ábra: A borfogyasztás alkalmai helyszínek alapján}

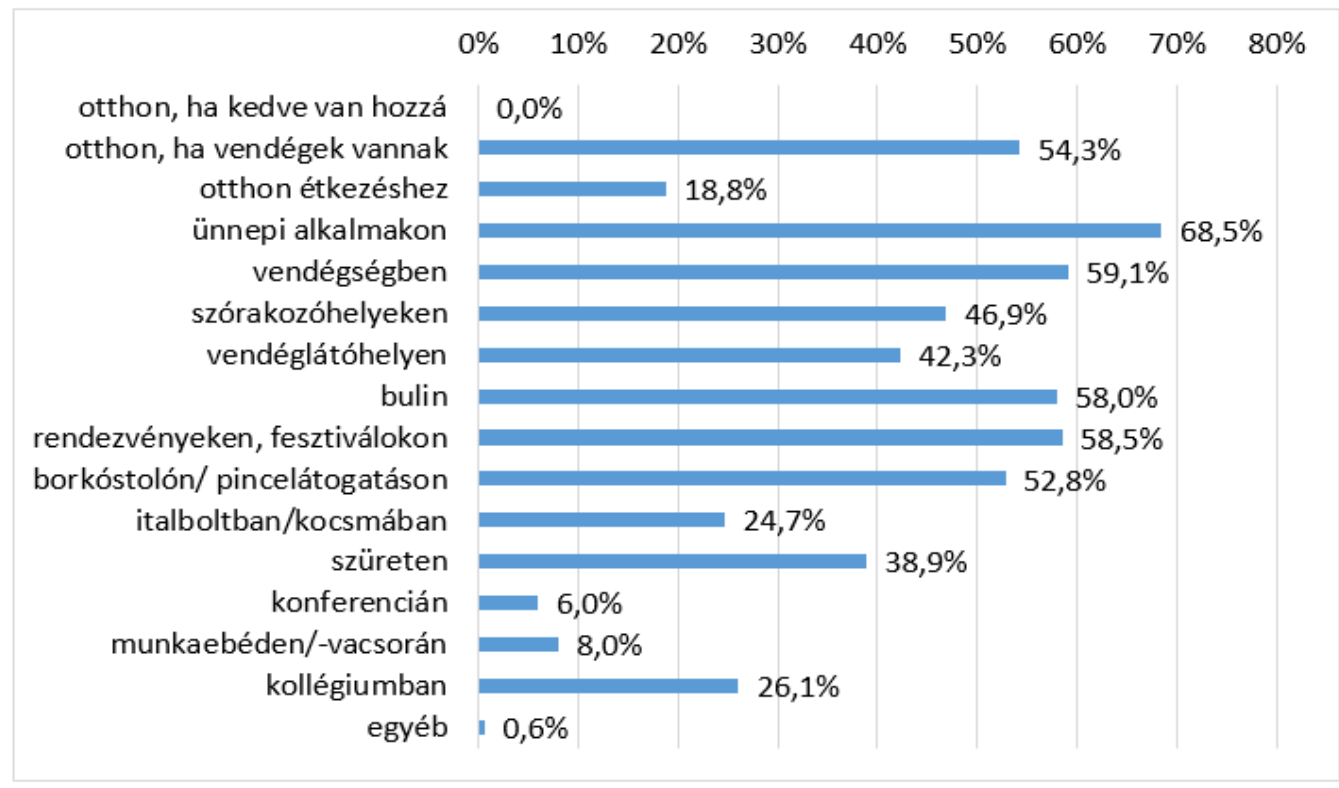

Forrás: Máté A.

A legtöbben ünnepi alkalmakon $(68,5 \%)$, vendégségben $(59,1 \%)$, rendezvényeken, fesztiválokon $(58,5 \%)$, és bulikban (58\%) fogyasztanak bort. A válaszadók fele akkor fogyaszt bort ha, otthon vendéget fogad $(54,3 \%)$ vagy borkóstolón, pincelátogatáson vesz részt $(52,8 \%)$. Ennél valamivel kevesebb azon válaszadók aránya, akik szórakozóhelyeken (46,9\%), vendéglátóhelyeken (42,3\%) vagy szüreten $(38,9 \%)$ fogyasztanak bort. A megkérdezett célcsoport sajátossága miatt megjelenik fogyasztási helyszínként a kollégium, ahol a válaszadók negyede $(26,1 \%)$ fogyaszt bort. A hallgatók negyede $(24,7 \%)$ italboltban, vagy kocsmában is fogyaszt bort. Csak kisebb arányban $(18,8 \%)$ jellemzö, hogy otthon, étkezések mellé is fogyasztanak bort. Szintén a célcsoport élethelyzetéböl adódik (hiszen a hallgatók háromnegyede nappali tagozatos, így kevesen vállalnak mellette munkát), hogy munkaebéden, munkavacsorán (8\%), vagy konferencián (6\%) még kevesen fogyasztanának bort, hiszen nem jellemző, hogy ezeken gyakran részt vennének. (4. ábra)

A kutatásból megállapítható, hogy legszívesebben a rozé bort fogyasztják a fiatalok $(73,4 \%)$ ezt követi a vörösbor $(58,2 \%)$ és csak kicsit lemaradva a fehérbor (52\%) kedveltsége. A megkérdezettek nem igazán fogyasztják a sillerbort (10,7\%). Tehát a fiatalok körében nagyon népszerü a rozé, viszont a siller alig ismert. A hallgatók több kedvelt borvidéket is megjelölhettek a kérdőívben, így a legtöbb említést a Villányi (67,2\%), a Szekszárdi $(51,1 \%)$, a Tokaji $(50,3 \%)$ és az Egri $(35,3 \%)$ borvidék kapta. Tehát a földrajzi közelségnek köszönhetően a térség borvidékei sokkal ismertebbek. A négy legkedveltebb borvidék közül három vörösboros borvidékünk. A bor cukortartalma alapján a válaszadók a legjobban az édes $(59,3 \%)$ és félédes $(46,6 \%)$ borfajtákat kedvelik, míg a száraz $(29,9 \%)$ és a félszáraz $(26,6 \%)$ borfajták kevésbé. Tehát a fiatalok ízlésének formálására és a száraz borok értékeinek megismertetésére továbbra is nagyon szükség van. A vörösbort adó szőlőfajták közül a Kékfrankos $(49,4 \%)$ és a Merlot $(42,1 \%)$ a legkedveltebb. A fehérbort adó szőlőfajták a népszerüségi sorrendje a következő, bár itt elég szoros a mezöny: Olaszrizling (41,5\%), Muskotály (40,3\%), Chardonnay (40\%), Irsai Olivér (37\%), Cserszegi füszeres $(34,2 \%)$. Tehát a hallgatók körében igen kedveltek a térségi, regionális szőlőfajtáink, az illatos, könnyebb bort adó fajták. Az ízlésvilágukban nem kerültek túlsúlyba a világfajták. A vörösbort adó szőlőfajták közül még a Cabernet Sauvignon-t (30,3\%), a Pinot Noir-t $(21,5 \%)$, a Zweigeltet $(20,9 \%)$ és a Kadarkát $(20 \%)$ említették jelentősebb arányban. A fehérbort adó szőlöfajtákból a Hárslevelü (27,3\%), a Sauvignon Blanc (22,1\%), a Szürkebarát $(21,2 \%)$ és a Furmint (20,3\%) fajtákat kedvelték még számottevő arányban. (5. ábra) 


\section{5. ábra: A kedvelt borfajta a szőlőfajták alapján}

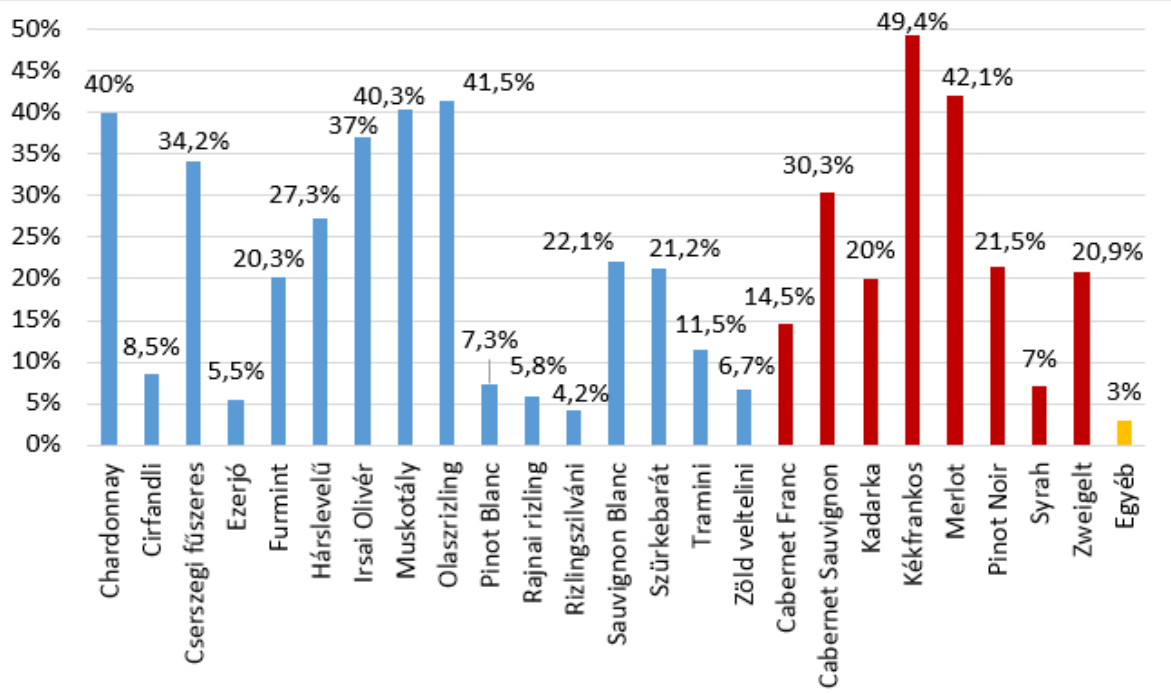

Forrás: Máté A.

A hallgatók válaszaiból jól látszik, hogy a négy legkedveltebb borvidék sorrendje a következő: a Villányi, a Szekszárdi, a Tokaji, az Egri. A válaszadók több borvidéket is jelölhettek. Így a válaszadók kétharmada $(67,2 \%)$ említette a Villányi borvidéket, fele-fele a Szekszárdi borvidéket $(51,1 \%)$ illetve a Tokaji borvidéket $(50,3 \%)$, és egyharmaduk az Egri borvidéket. A négy legkedveltebb borvidék közül 3 vörösboros borvidékünk. A hallgatók körében népszerüek még a Balatoni borrégió egyes borvidékei (Badacsonyi, Balatonboglári, Balaton-felvidéki) is. A válaszadók negyede $(24,9 \%)$ kedveli a Pécsi borvidéket, azonban csak 8,5\% a Tolnai borvidéket. Tehát az egyetem pécsi és szekszárdi telephelyei révén a Pannon borrégió három borvidékéhez erős kötödést tud kialakítani a hallgatók körében. A többi hazai borvidék említése $10 \%$ alatti volt. (6. ábra)

\section{6. ábra: A hallgatók által leginkább kedvelt borvidékek}

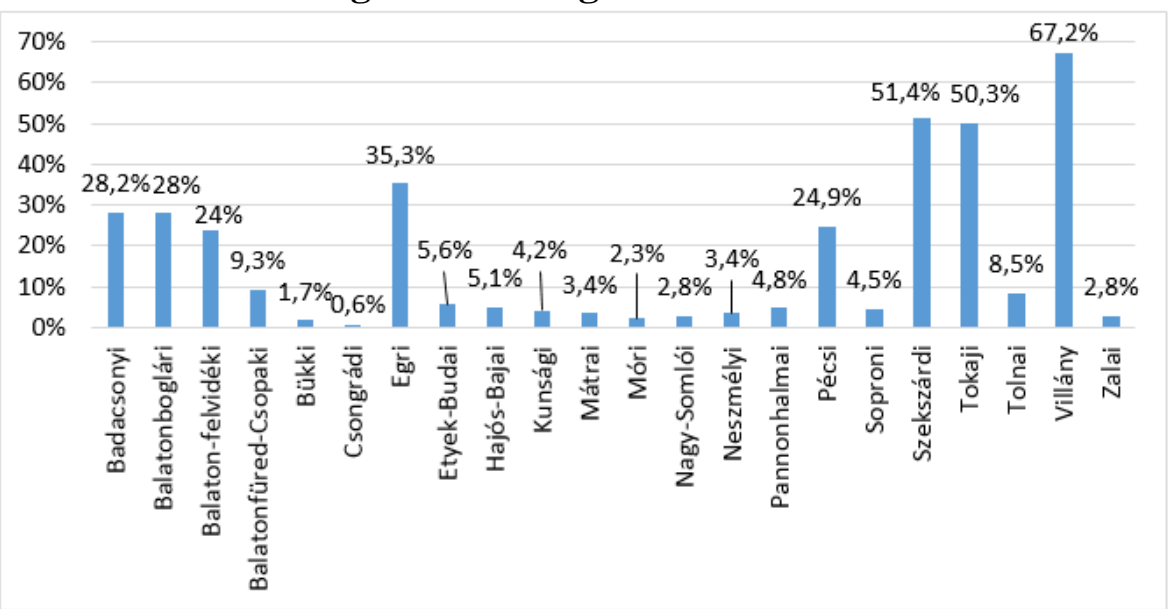

Forrás: Máté A.

A válaszadók három kedvelt pincészetet jelölhettek meg a kérdöívben, így 141 különböző borászatot neveztek meg, és összesen 465 említés született. A legtöbb megkérdezett a Villányi (17,7\%), a Szekszárdi (14,9\%) és a Pécsi (11,3\%) borvidékről nevezett meg pincészetet. Az egyes borvidékekhez tartozó pincészetek említésének száma alapján - egyszerre ugyanis több pincészetet is említhettek a válaszadók egy borvidékről - is ugyanez a három borvidék került az élre: a Villányi $(27,5 \%)$, a Szekszárdi $(26,7 \%)$ és a Pécsi $(8 \%)$ borvidék. Tehát a földrajzi közelségnek köszönhetően a térség pincészeteit sokkal jobban ismerik. 
Emellett még a Badacsonyi (7,8\%), a Tokaji (6,4\%), a Balatonboglári (5\%), az Egri (5\%) és a Tolnai (5\%) borvidékekről neveztek meg kedvelt pincészeteket. Az említések száma azonban csak Badacsonyi $(7,1 \%)$, a Tokaji $(6,2 \%)$ és a Balatonboglári $(5,4 \%)$ borvidéknél volt jelentősebb. Négy borvidékröl nem említettek pincészetek a hallgatók, ezek a Bükki, Csongrádi, Nagy-Somlói és Zalai borvidékek voltak (7. ábra).

7. ábra: Kedvelt pincészetek borvidék és említések szerinti megoszlása

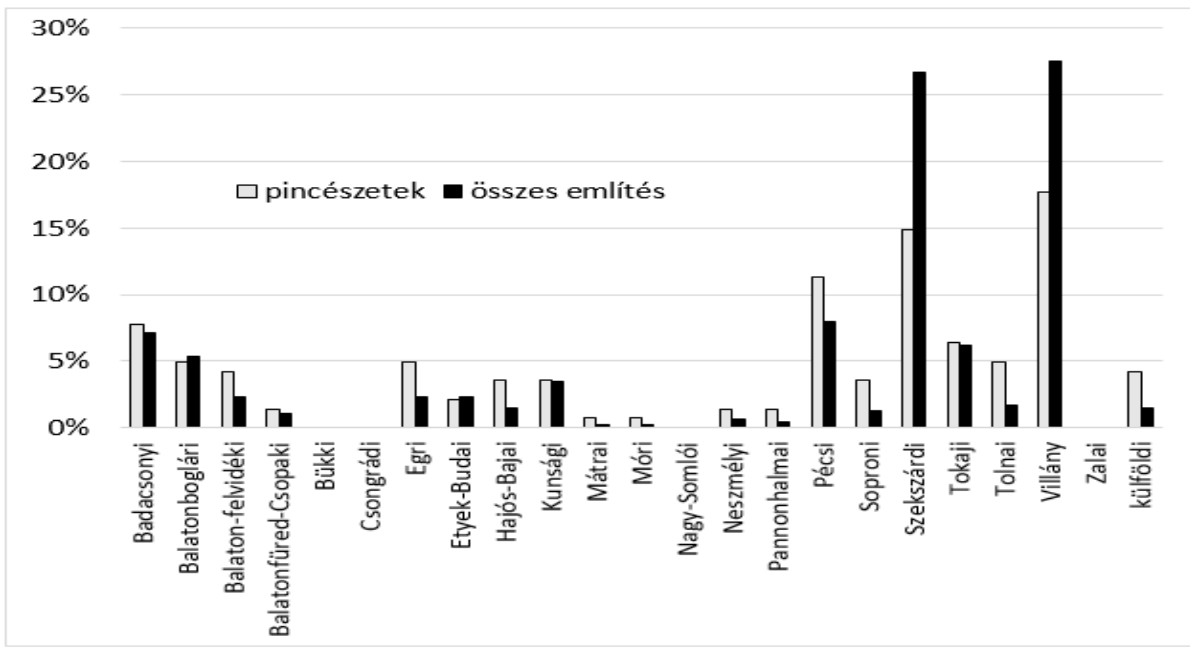

Forrás: Máté A.

A válaszadók jelentős része egyetért azzal, hogy a fiatalok körében egyre népszerübb a borfogyasztás $(3,83)$, hogy menő dolog ismerni néhány borászt $(3,49)$. (1. táblázat)

1. táblázat: A borfogyasztással kapcsolatos állítások értékelése

\begin{tabular}{lr}
\hline \multicolumn{1}{c}{ Állítások } & Átlag \\
\hline A fiatalok körében egyre népszerübb a borfogyasztás. & 3,83 \\
\hline Az elmúlt években jelentősen nőtt a fiatalok tudása a borról. & 2,99 \\
\hline A fiatalok körében kezd divatos lenni a helyi borok fogyasztása. & 3,32 \\
\hline Menő dolog ismerni néhány borászt. & 3,49 \\
\hline Ciki vörösboros kólát inni. & 2,69 \\
\hline Ciki fröccsöt inni. & 1,55 \\
\hline Menő rozé-fröccözni. & 3,48 \\
\hline A jövőben divatosabb lesz a fröccsözés. & 3,56 \\
\hline A borfogyasztás része az értelmiségi létnek. & 3,35
\end{tabular}

Forrás: Máté A.

Megjegyzés: ahol „, 1 ” az egyáltalán nem ért egyet és ,,5” a teljes mértékben egyetértek kategóriát jelenti 
Csak kevés fiatal gondolja úgy, hogy ciki fröccsöt inni (1,55), vagyis ez a hungarikum elfogadottabb és egyre kedveltebb a fiatalok körében is. Úgy vélik a jövőben még divatosabb lesz a fröccsözés $(3,56)$ és szerintük menő rozé fröccsöt inni $(3,48)$. A vörösboros kóláról azonban megoszlanak a vélemények $(2,69)$, vagyis $49 \%$ szerint nem ciki vörösboros kólát inni, míg $29 \%$ szerint ciki. Csak részben értenek egyet azzal, hogy az elmúlt években jelentősen nőtt a fiatalok tudása a borról $(2,99)$, hogy a fiatalok körében kezd divatos lenni a helyi borok fogyasztása $(3,32)$, és hogy a borfogyasztás része az értelmiségi létnek $(3,35)$.

Bár egyre kedveltebb a fiatalok körében is a borfogyasztás, a hozzá kapcsolódó ismeretek, tudás még hiányos a körükben. A hallgatók még nem azonosítják egyértelmüen a kulturált borfogyasztást az értelmiségi léttel, tehát a fiatalok ismereteinek bővítésére továbbra is nagy szükség van.

\subsection{Borvásárlási szokások vizsgálatának eredményei a Pécsi Tudományegyetem hallgatói körében}

A válaszadók $82 \%$-a szokott bort vásárolni, míg 18\%-a nem. Akik nem vásárolnak bort, azok fele azért nem teszi, mivel van saját (a család által készített) boruk. A kutatásban résztvevők 96\%-a elsősorban palackos bort vásárol, és csak nagyon alacsony arányban jellemző a folyóbor $(2,6 \%)$ vagy a bag in box bor $(1,4 \%)$ vásárlása.

A válaszadók körében a saját fogyasztás céljából történő vásárlás esetén a legfontosabb tényező az ár (77,5\%) volt, majd az íz (77\%) és a minőség (74,5\%) következett. (8. ábra) Fontos tényezők voltak: a szőlőfajta (43\%) és a borvidék (42,7\%). Közepesen fontos szempont volt: az ismerös ajánlása $(33,3 \%)$, a bor színe $(32,3 \%)$ és az évjárat (29,3\%). A legkevésbé befolyásoló tényező a palack formája $(7,4 \%)$, és a szakértő ajánlása $(11,5 \%)$ volt. A megkérdezettek szerint bor ajándékozása esetén a vásárlást befolyásoló legfontosabb tényező a minőség (82\%). Egyéb fontos tényező lehet még: az íz (55,5\%) és az ár (55,5\%); majd ezt követték a borvidék (49,5\%), az évjárat $(46,2 \%)$ és a márka $(42,1 \%)$. Közepesen fontos szempont lett: a szőlőfajta $(31,7 \%)$, a címke (30,9\%), a borász ismertsége (29\%), a palack formája (28,4\%). Legkevésbé fontosnak a szakértők $(14,8 \%)$ és az ismerősök (16,4\%) ajánlását tartották. Tehát ajándékozás esetén a bor minősége jóval fontosabb, mint az ára, és felértékelődik az esztétikai elemek, a márka, és a borász személye tényezőként (8. ábra).

\section{8. ábra: A borvásárlás szempontjai saját fogyasztás és ajándékozás esetén}

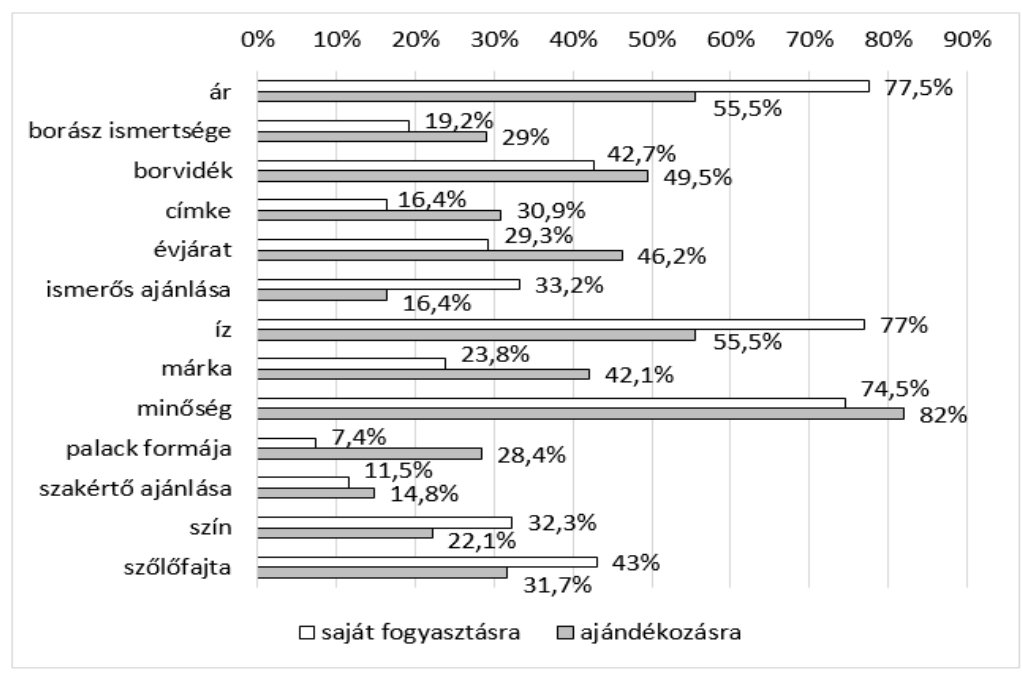

Forrás: Máté A.

A válaszadók többsége hiper- és szupermarketekben (58\% és 52,6\%) vásárol, valamint közvetlenül a termelöknél $(56,6 \%)$. 
A hiper- és szupermarketek elsősorban a városokra jellemző értékesítési csatornák, amellyel a két egyetemi székhely jól ellátott. A borvidékek közelsége pedig kedvező feltételt biztosít, hogy a termelöknél, vagy borszaküzletben $(44,2 \%)$ tudjanak vásárolni a válaszadók. (9. ábra)

\section{9. ábra: A borvásárlás megoszlása értékesítési csatornák szerint}

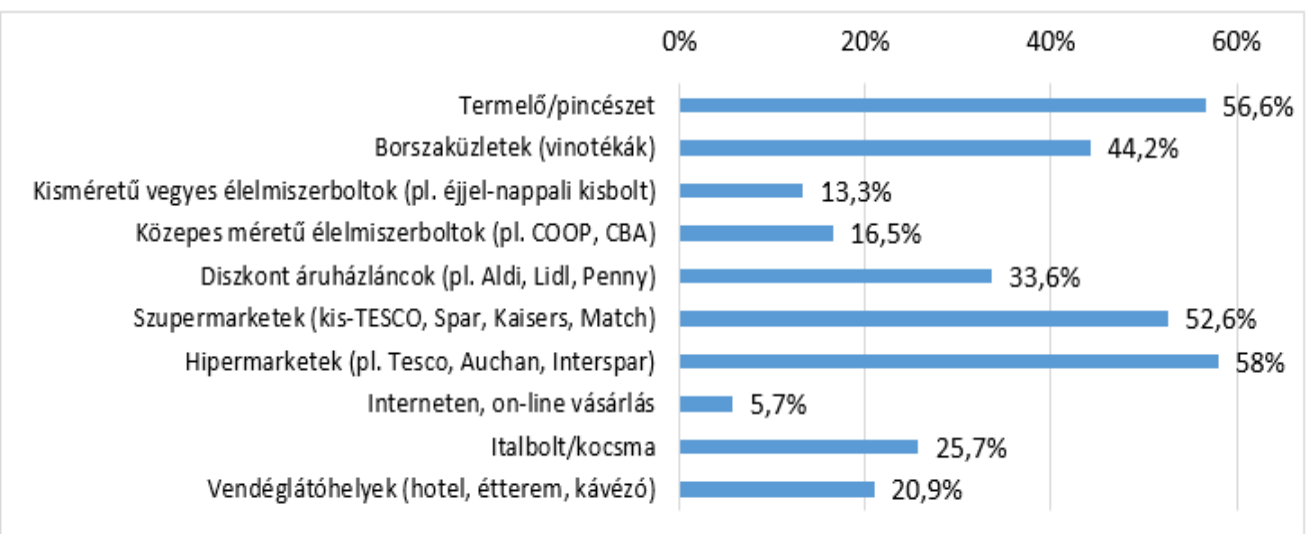

Forrás: Máté A.

Olcsósága miatt kedvelt vásárlási helyszínek a diszkont áruházláncok (33,6\%). A társasági fogyasztás miatt jelentős szerepe van az italbolt/kocsma $(25,7 \%)$ és a vendéglátás $(20,9 \%)$ értékesítési csatornának. A legalacsonyabb arányt az online borvásárlás $(5,7 \%)$ képviseli, hiszen a termelök helyben vannak, könnyen elérhetőek (2. táblázat). Saját fogyasztásra a válaszadók harmada $(30,1 \%) 1000 \mathrm{Ft}$ alatt költene, majdnem a fele (44,6\%) 1000-2000 Ft között és csak a negyede $(25,3 \%) 2000 \mathrm{Ft}$ felett. A legdrágább kategóriát (5000 Ft felett) 3,6\%-a, míg a legolcsóbbat (500 Ft alatt) 2,5\%-a választotta (2. táblázat). Ajándékozás esetén a válaszadóknak csak 3,4\%-a költene 1000 Ft alatt, 43\% az 1000- 2000 Ft között, míg több mint a fele $(53,6 \%) 2000$ Ft felett.

\section{2. táblázat: Költési hajlandóság egy palack borért saját fogyasztásra, ajándékozásra, ünnepi alkalomra}

\begin{tabular}{|l|c|c|c|}
\hline $\begin{array}{c}\text { Alkalom/ } \\
\text { költési } \\
\text { hajlandóság (Ft) }\end{array}$ & ünnepi alkalomra & ajándékozásra & $\begin{array}{c}\text { saját } \\
\text { fogyasztásra }\end{array}$ \\
\hline $500 \mathrm{Ft}$ alatt & $0,6 \%$ & $0,3 \%$ & $2,5 \%$ \\
\hline $500-799 \mathrm{Ft}$ & $0,6 \%$ & $0,3 \%$ & $14,8 \%$ \\
\hline $800-999 \mathrm{Ft}$ & $3,6 \%$ & $2,8 \%$ & $12,8 \%$ \\
\hline $1000-1199 \mathrm{Ft}$ & $8,0 \%$ & $8,9 \%$ & $17,0 \%$ \\
\hline $1200-1499 \mathrm{Ft}$ & $12,5 \%$ & $15,5 \%$ & $15,9 \%$ \\
\hline $1500-1999 \mathrm{Ft}$ & $19,4 \%$ & $18,6 \%$ & $11,7 \%$ \\
\hline $2000-2499 \mathrm{Ft}$ & $15,2 \%$ & $15,5 \%$ & $9,5 \%$ \\
\hline $2500-2999 \mathrm{Ft}$ & $15,8 \%$ & $16,6 \%$ & $6,4 \%$ \\
\hline $3000-3999 \mathrm{Ft}$ & $8,6 \%$ & $6,4 \%$ & $3,3 \%$ \\
\hline $4000-4999 \mathrm{Ft}$ & $5,0 \%$ & $7,2 \%$ & $2,5 \%$ \\
\hline $5000 \mathrm{Ft}$ felett & $10,8 \%$ & $8,0 \%$ & $3,6 \%$ \\
\hline
\end{tabular}

Forrás: Máté A. 
A legdrágább kategóriát (5000 Ft felett) 8\%, míg a legolcsóbbat (500 Ft alatt) 0,3\% választaná. Ünnepi alkalom esetén a költések közel hasonlóan alakulnának, mint az ajándékozásnál, minimálisan lenne több a 2000 Ft feletti vásárlási hajlandóság $(55,4 \%)$. A válaszadóknak csak 4,8\%-a költene 1000 Ft alatt, és 39,8\% az 1000-2000Ft között. A legdrágább kategóriát (5000Ft felett) 10,8\%, míg a legolcsóbbat (500 Ft alatt) 0,6 \% választaná (2. táblázat). Tehát saját fogyasztásra költenék a legkevesebbet, míg ajándékozásra többet, és csak minimálisan költenének többet ünnepi alkalomra.

Tehát a borvásárlási hajlandóság meredeken emelkedik ajándékozás és ünnepi alkalom esetén az 500 Ft-os kategóriától egészen a 3000 Ft-os értékig, ennél drágább boroknál azonban már meredeken zuhan azok aránya, akik hajlandóak megvenni egy palack bort ajándékozásra vagy ünnepi alkalomra. Saját fogyasztás esetén pedig határozott trendvonal húzható 1000 Ft-tól 5000 Ft-ig, vagyis az ár emelkedésével szinte egyenes arányban csökken a vásárlási hajlandóság. A három kategória trendvonalának metszete 1200-2000 Ft között mozog. Fontos megjegyezni, hogy 500 Ft alatti palackáron minimális a vásárlás, tehát az alsó kategóriás, alacsonyabb minőségü borok szegmensének (szerencsére) az egyetemisták nem képezik piacát. A fiatalok leginkább az 500-1500 Ft-os árkategóriából válogatnak.

\subsection{A borral kapcsolatos ismeretek forrása és bővítésének hajlandósága}

A megkérdezettek a borokkal kapcsolatos információk jelentős részét barátoktól, ismerősöktől (84,3\%), családtól, rokonoktól (71\%), valamint közösségi oldalról $(24,7 \%)$ és az iskolától $(24,1 \%)$ szerzik be. Ez utóbbi esetében elsősorban a felsőoktatást kell kiemelni, mivel a közoktatás a 18 év alattiak alkoholfogyasztási tilalma miatt nem foglalkozik a felelős alkoholfogyasztás kérdésével. A felsőoktatásnak fontos szerepe lehet abban, hogy a hallgatók megfelelő alapismereteket kapjanak a kulturált borfogyasztás világáról. A fiatalok megszólításához, ismeretek átadásához a közösségi oldalak egyre fontosabb forrássá válnak, ezért ezek tudatos kialakítása a jövőben még fontosabb feladat lesz. (10. ábra)

10. ábra: Válaszadók információi a borokról

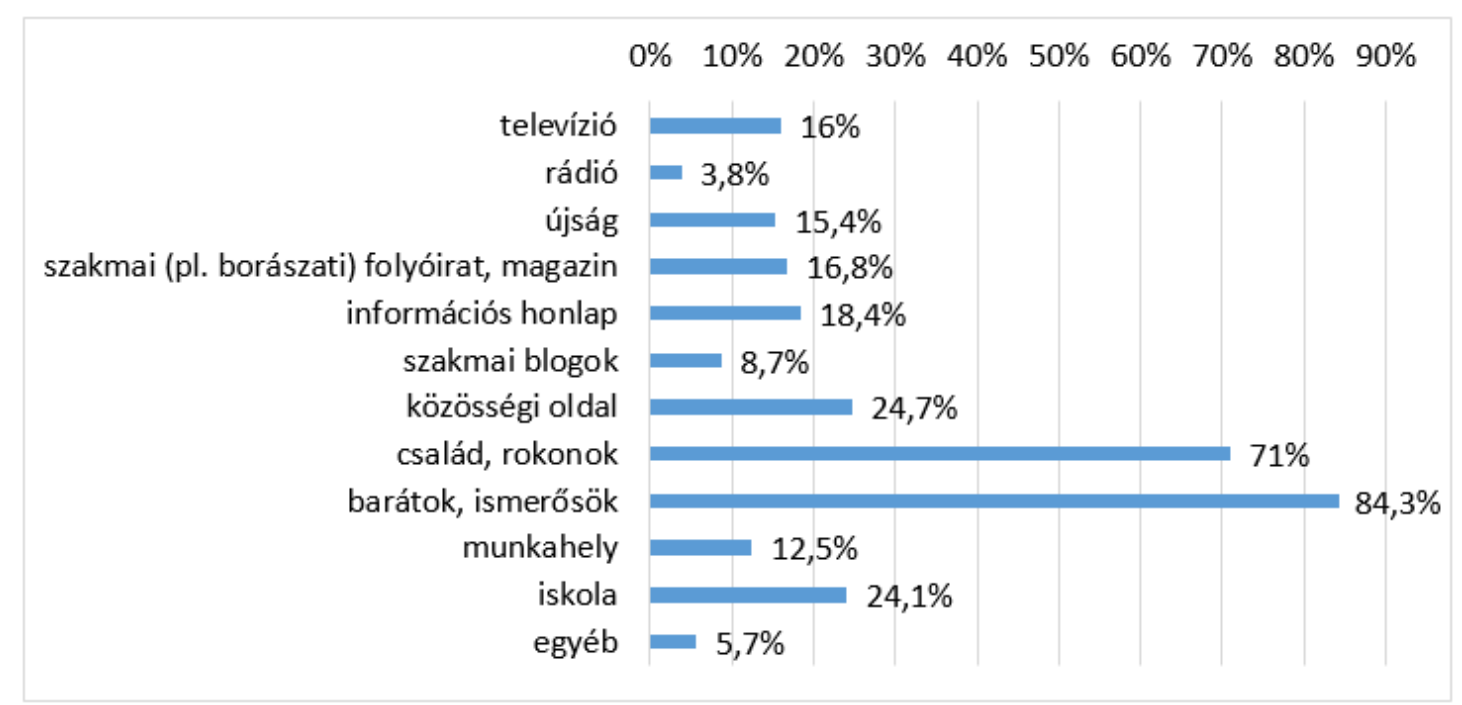

Forrás: Máté A.

A válaszadók 98\%-a szívesen látogatna valamilyen borral kapcsolatos rendezvényt, leginkább pincelátogatáson, borkóstolón $(79,9 \%)$, szüreti fesztiválon $(78,3 \%)$, borvacsorán $(58,3 \%)$ vennének részt (3. táblázat). 
3. táblázat: Borral kapcsolatos programon való részvételi hajlandóság

\begin{tabular}{lr}
\hline Megnevezés & Értékek \\
\hline pincelátogatáson és borkóstolón & $79,9 \%$ \\
\hline szüreti fesztiválon & $78,3 \%$ \\
\hline borvacsorán & $58,3 \%$ \\
\hline borvidéki gyalogtúrán & $32,0 \%$ \\
\hline borhoz kapcsolódó múvészeti (pl. zenei, képzőmüvészeti) & $30,1 \%$ \\
rendezvényen & \\
\hline Márton-napi rendezvényen & $29,3 \%$ \\
\hline szervezett borúti programcsomagon & $28,7 \%$ \\
\hline borkultúra szabadegyetemen & $27,1 \%$ \\
\hline borvidéki futóversenyen, félmaratonon & $14,1 \%$ \\
\hline nem vennék részt szívesen borral kapcsolatos programon & $1,9 \%$ \\
\hline
\end{tabular}

A Pannon Borrégió széles kínálatot nyújt ezekből a szolgáltatásokból, itt inkább a hallgatók fizetőképes kereslete szabhat határt a lehetőségeiknek. A szüreti napok sokasága várja ősszel a látogatókat a borrégióban, amelyek legtöbbször kiegészülnek folklór, kulturális és müvészeti programokkal is (GULD 2011, MÁTÉ 2013). Kisebb arányban, de szívesen részt vennének borvidéki gyalogtúrán (32\%), borhoz kapcsolódó mủvészeti rendezvényen (30,1\%), Márton-napi rendezvényen $(29,3 \%)$, szervezett borúti programcsomagon $(28,7 \%)$, borkultúra szabadegyetemen $(27,1 \%)$. A pályázati forrásokból létrejött borutak eltérő intenzitással müködnek, így az általuk kialakított programkínálat is széles skálán mozog (GONDA — RAFFAY 2015, MÁTÉ 2013, 2007). A Mártonnap az újbor szentelésének és a liba lakomáknak az időszaka minden novemberben, amely jó alkalmat teremt arra, hogy ne csak borvacsorákon vegyenek részt a látogatók a pincészeteknél, hanem kapcsolódó turisztikai rendezvények keretében a borvidék más értékeit is felfedezzék (GULD et al. 2014). A Pécsi Tudományegyetem már 2009 óta szervez Borkultúra Szabadegyetem programot Szekszárdon, amely sikerének köszönhetően, valamint a Dél-Dunántúli Borklaszter támogatásával Pécsett is elindult ez a programsorozat. Tehát a hallgatók már két helyszínen is be tudnak kapcsolódni a rendezvénybe (GONDA 2014, 2013, GULD 2011, OROSZI et al. 2015). A borvidéki futóversenyek keltették fel legkevésbé (14,1\%) a válaszadók érdeklődését, pedig például a 2010 óta évente megrendezett szekszárdi Borvidék félmaraton futóverseny egyre nagyobb népszerüségnek örvend és 2015-ben már több mint 1500 fö résztvevőt regisztráltak.

A válaszadók háromnegyede (74,5\%) szívesen bővítené ismereteit a borral kapcsolatban, 10,6\%-a nem bővítené ismereteit, míg 14,9\%-a még bizonytalan, ezért ők még meggyőzendő célcsoport. A megkérdezettek $84 \%$-a szívesen részt venne borral kapcsolatos képzéseken. A hallgatók csaknem fele $(45,8 \%)$ legszívesebben borszemináriumot látogatna, pl. szabadon választható tantárgyként. (4. táblázat) 
4. táblázat: Borral kapcsolatos képzésen való részvételi hajlandóság

\begin{tabular}{lr}
\hline Megnevezés & Értékek \\
\hline borszemináriumon (pl. szabadon választható tantárgyként) & $45,8 \%$ \\
\hline borgasztronómiai képzésen & $35,2 \%$ \\
\hline gyakorlati képzésen borkultúra szabadegyetem keretében & $30,9 \%$ \\
\hline borszakértó képzésen & $31,7 \%$ \\
\hline borturisztikai képzésen & $25,7 \%$ \\
\hline szőlész-borász képzésen & $22,5 \%$ \\
\hline sommelier képzésen & $21,7 \%$ \\
\hline borbíráló képzésen & $17,3 \%$ \\
\hline bormarketing képzésen & $16,8 \%$ \\
\hline borkultúra és múvészeti képzés & $16,8 \%$ \\
\hline borjogi képzésen & $4,3 \%$ \\
\hline WSET tanfolyamon & $2,2 \%$ \\
\hline nem vennék részt szívesen borral kapcsolatos képzésen & $16 \%$ \\
\hline
\end{tabular}

Forrás: Máté A.

Az egyharmadukat érdekelné borgasztronómiai képzés $(35,2 \%)$, borszakértő képzés $(31,7 \%)$, gyakorlati képzés borkultúra szabadegyetem keretében (30,9\%). A szekszárdi Borkultúra Szabadegyetem programján a hallgatók jelenleg is részt vehetnek gyakorlati képzés keretében szervezőként, felszolgálóként (GULD 2011). A hallgatók negyede szívesen részt venne borturisztikai képzésen (25,7\%). A válaszadók egyötödét érdekelte a szőlész-borász képzés $(22,5 \%)$ és a sommelier képzés $(21,7 \%)$. Kisebb arányban érdeklődtek a borbíráló képzés $(17,3 \%)$, bormarketing képzés $(16,8 \%)$, borkultúra és müvészeti képzés $(16,8 \%)$ iránt. A borjogi képzés és a WSET (Wine \& Spirit Education Trust) tanfolyam érdekelte legkevésbé a hallgatókat. A borjog meglehetősen speciális szakmai terület. A WSET tanfolyamok sikeres vizsga esetén Wine \& Spirit Education Trust oklevelét adják, amely borismereti képzésék még nem igazán ismertek a hallgatók körében. (4. táblázat)

\subsection{Garay Élménypince mint az akadálymentes borkóstolás színtere}

A Pécsi Tudományegyetem szekszárdi Kara szőlész-borász képzéseinek kapcsán nem csak a kulturált és mértékletes borfogyasztás népszerüsítését tüzte ki célul, hanem a gyakorlatias oktatás megvalósítását is. Gyakorlati helyszínek között megjelennek a szekszárdi borászatok és a Pannon borrégió borturisztikai szempontból egyik legfontosabb helyszíne a Szekszárdi borvidék föld alatti élménykörútja, ami nem más, mint a város egykori, több száz éves dézsmapincéje, melyet Szekszárd város 2012-ben vásárolt meg. A közel kétszázmillió forintos uniós támogatás révén nyílt interaktív kiállítás minden apró részletében a bor és a borkultúra témájával foglalkozik. A múzeumok, kiállítások létfontosságú szerepet játszanak a kulturális értékek hozzáadásában. (MÁTÉ 2020)

Egy olyan pincerendszerről van szó, melynek három nagyobb járata közül kettő 40 méter hosszan húzódik a vármegyeháza alatt. A pincerendszer alapjait feltehetően az 1061-ben alapított bencés apátság hozta létre a 13-16. század között, de a jelentősebb része a török hódoltságot követően, az 1700-as évek első felében épült meg. Az is említésre méltó, hogy 1856-ban itt alakult meg az első hazai borkereskedő részvénytársaság. 
A Garay Élménypince olyan méretü, jellegű és színvonalú bemutatóterem, amely egyedülálló Magyarországon. Akár több csoport egyidejü befogadására is képes, legyen szó magyar vagy külföldi érdeklődőkről. Az interaktív kiállítást még értékesebbé teszi, hogy a borkedvelők több nyelven is kaphatnak információt szekszárdi borokról, szekszárdi borászokról, a borkóstolás rejtelmeiröl, borkultúráról, borgasztronómiáról. (1. kép)

\section{1. kép: Infografikai tablók és interaktív felületek}

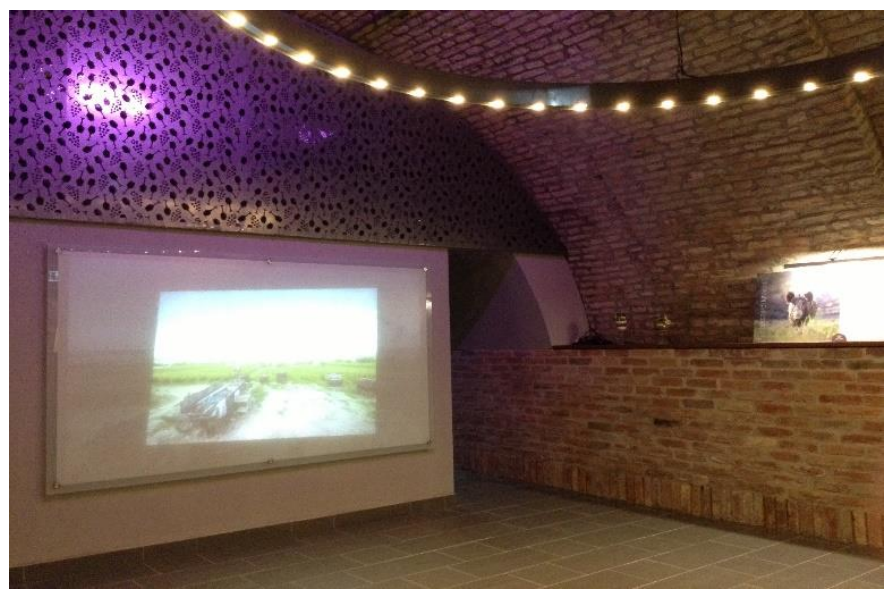

Forrás: Saját fotó

A 13. századi eredetü létesítményben egyebek mellett 65 tabló és 11 interaktív eszköz kapott helyet, melyek rengeteg színes és informatív leírást nyújtanak a szekszárdi borról, a borkultúráról, magáról a Szekszárdi borvidékről rendkívül sok érdekes információval szolgálnak magyar, angol és német nyelven.

\section{2. kép: Gasztrokerék}

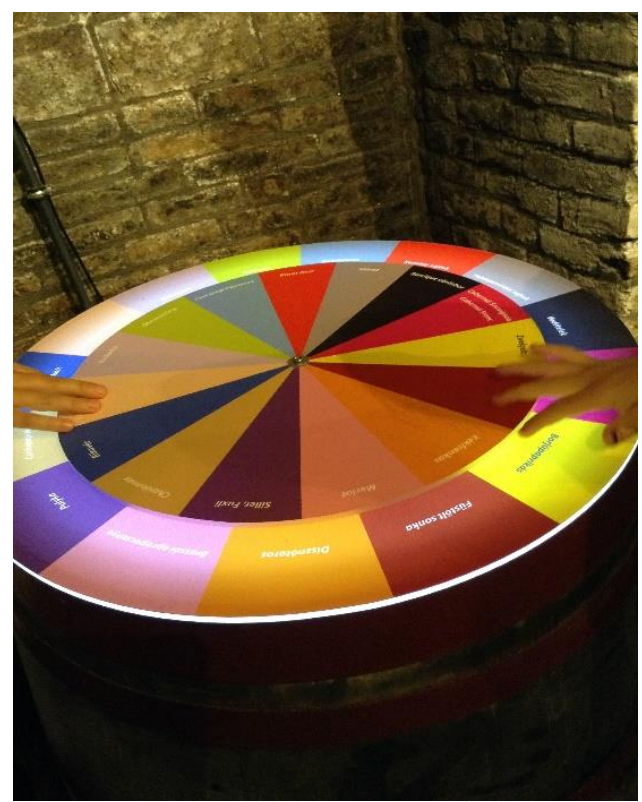

Forrás: Saját fotó

Az izgalmas élményelemek sorában speciális illatkapszulák segítségével a borokra jellemző egyedi illatok is érzékelhetők, a gasztrokeréken (2. kép) pedig megtekinthető, hogy melyik szekszárdi borfajtához milyen étel illik a legjobban; s bárki kipróbálhat egy különleges, digitális borbíráló programot is az úgynevezett „surface” asztalon. 
A vendégnek annyi a dolga, hogy kiválasztja az adott bort amit szeretne megkóstolni, leteszteli, majd a kóstolást követően pontozza a bort szín, tisztaság, illat, összbenyomás alapján. Végül eredményként megkapja, hogy számára az adott minta milyen kategóriába esik.

Három és fél órás élményprogram keretében, korszerü és modern technikai elemek segítségével a szőlő metszésétől a borfogyasztáson át, egészen a borkóstolás apró részleteivel ismerkedhetnek meg a látogatók. Három illatkamra segítségével a fehér-, vörös- és rozéborra jellemzö illatmintákkal, üvegekben elhelyezett illatkapszula révén a borokra jellemző egyedi illatokkal ismerkedhetnek meg mind a laikus, mind a hozzáértőbb látogatók. (3. kép) A pincebejárást követően egy érintőképernyőn megjelenő feladatsor kitöltésével meggyőződhetünk arról, hogy a borról, a borkészítési technológiákról, a bor fogyasztásának kultúrájáról vagy a Szekszárdi borvidékről olvasott információkat elraktároztuk-e.

\section{3. kép: Vörösbor illatkamra}

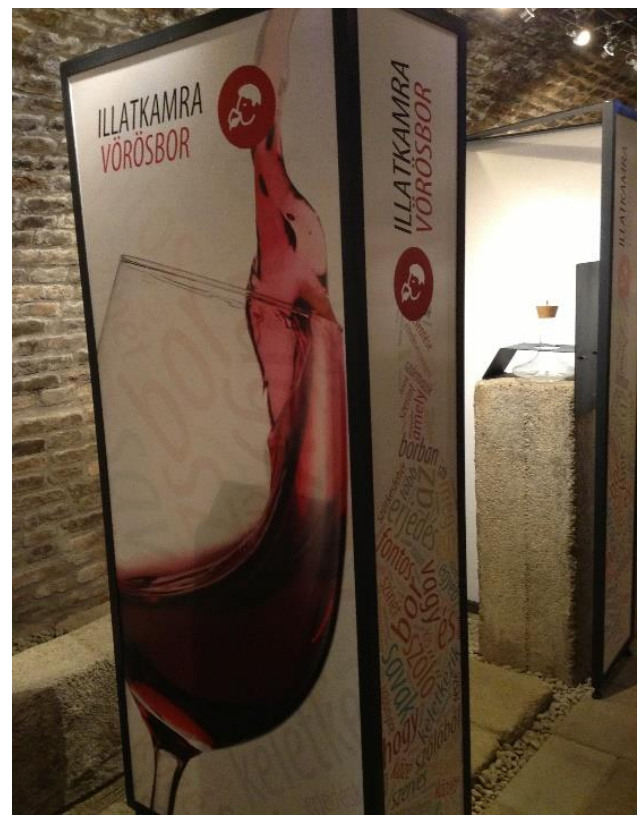

Forrás: Saját fotó

A föld alatti borélmény-körutat a teljes körü akadálymentesítésnek köszönhetően a látás-, a hallássérültek, valamint a mozgáskorlátozottak, kerekes székesek is végigjárhatják. Az érdeklődők a létesítményt 787 négyzetméteren élvezhetik, másrészt az elötérben 31 szekszárdi borászat és 2 pálinkaház - Brill Pálinkaház és Savanya Pálinkaház - több mint 220 fajta nedüjéből vásárolhatnak, harmadrészt pedig ízletes étkek várják őket a létesítmény 70 fös éttermi részében. Az élménypince rendkívüli előnye abban rejlik, hogy egyetlen helyszínen biztosítja a Szekszárdi borvidék minden látnivalóját, borászatait és borait; — ami a fogyatékkal élők részére nagy segítség abban, hogy a borvidéket nem kell bejárniuk. Óriási távolságok vannak egyes neves pincészetek között, hogy csak két példát említsek, a Pannon Borrégió egyik legdinamikusabban fejlődő borvidékén, a Szekszárdi borvidéken, egyes borászatok rendkívül távol esnek egymástól, - például a Takler Pince és a Vesztergombi Pince között közel 20 km távolság van.

A Kadarka Nagyterem 60 fös baráti vagy céges rendezvények lebonyolítására is alkalmas kellemes helység. (4. kép) Nagy előnye a pincének, hogy egy zártkörü rendezvény mellett zavartalanul járhatják körbe az élményteret a betévedö borturisták. A nagyterem egy éve ad otthont egy programsorozatnak, ami során alkalom nyílik a tematikus, vertikális és horizontális kóstolók mellett a szükebben vett borfogyasztási kultúra alapvető ismereteinek elsajátítására, és a tágabban értelmezendő borkultúra, a borhoz kapcsolódó művészeti, történeti vonatkozású ismeretekbe való bepillantásra. Az egyes programok önmagukban is értékesek, valamint élvezetes kóstolókat és előadásokat tartalmaznak. Kitünő társasági program. 
A programok átfogó képet adnak a magyar borvidékekről, azok minőségi borairól, és kitűnő pincészeteiről, a változó borfogyasztási szokásokról, a kóstolási technikákról. (SLEZÁKBARTOS et. al. 2020)

\section{4. kép: Kadarka Nagyterem}

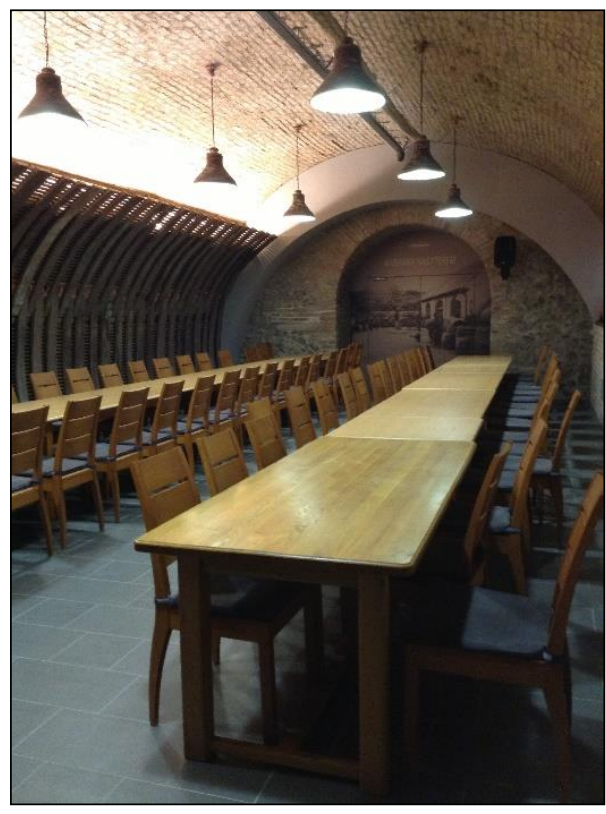

Forrás: Saját fotó

\section{Következtetések}

A felsőoktatásban megjelenő hallgatók a kulturált borfogyasztás potenciális piaca, ezért kiemelten fontos a fiatal felnőttek fogyasztási szokásainak vizsgálata. A fiatalok fogyasztási szokásai még változóban vannak, így megfelelö ismeretek átadással, kulturált borfogyasztást népszerüsítő programokkal tudatos fogyasztókká válhatnak, és ebben az egyetemnek meghatározó szerepe lehet. Tanulmányunk első részében a Pécsi Tudományegyetemen megkérdezett diákok alapvető borfogyasztási szokásait kívántuk bemutatni. Az általunk megkérdezett fiatal felnőttek - az egyetem vonzáskörzetének köszönhetően is - döntő többsége Tolna és Baranya megyéből került ki. A kérdöívben felsorolt alkoholos italok közül legkedveltebb a bor, legkevésbé kedvelt a pálinka volt. A megkérdezettek csaknem $96 \%$-a fogyaszt bort, és mindössze 4\%-uk az, aki egyáltalán nem, elsősorban a bor ízvilága miatt. A bort fogyasztók többsége (40,2\%-a) alkalmanként 3-5 deciliter bort fogyaszt. Mindössze 5\% fogyaszt alkalmanként 1 liternél nagyobb mennyiséget, amely már bőven meghaladja az egészséges mérteket. A többségük - a fiatalságtól talán kevésbé megszokott módon - tisztán fogyasztja a bort. Emellett a bort nagyobb arányban fogyasztják szódával, mint kólával, amely szintén mutatja a fiatalok fogyasztási szokásainak változását. Különösen a rozéfröccs vált kedvelté a fiatalok körében. A borfogyasztás helyszínei igen változatosak, leginkább valamilyen családi, baráti eseményhez, vagy szabadidős tevékenységhez (pl. fesztivál) társul a borfogyasztás. A borfajták közül legkedveltebbnek a rozé bizonyult, melyet a Pannon Borrégió népszerü borvidékeinek meghatározó fajtái, a vörösborok követnek. A hallgatók körében igen kedveltek az illatos, könnyebb bort adó fajták (Irsai Olivér, Cserszegi füszeres) és a térségi, regionális szőlőfajtáink (Olaszrizling, Muskotály, Kékfrankos). Az ízlésvilágukban nem kerültek túlsúlyba a világfajták (Merlot, Chardonnay). Az egyetem földrajzi elhelyezkedéséből is adódik, hogy a válaszadók a Villányi és a Szekszárdi borvidéket kedvelik a legjobban. A bor cukortartalma alapján az édes, félédes borok örvendenek a legnagyobb népszerüségnek. Ezek a kutatási eredmények is alátámasztják a DULA és munkatársai (2012) által a fiatalok borfogyasztási szokásaikra tett megállapításokat. A gyöngyöző bor, a siller nem közismertek a fiatalok számára. A pálinkáról a legnegatívabb a véleményük, annak ellenére, hogy a termelés jelentősen elmozdult a minőségi pálinkakészítés irányában. 
Fogyasztásukban még mindig tartanak a száraz borok ízvilágától. Tehát továbbra is szükség van olyan programok szervezésére, ahol tudásukat bővíthetik és a kedvezőtlen véleményüket gyakorlati ismeretek segítségével megváltoztathatjuk. Emellett pedig továbbra is fel kell hívni a figyelmet a kulturált és felelős alkoholfogyasztásra. A kutatás visszaigazolta, hogy pozitív irányba fejlődnek a fiatalok borfogyasztási szokásai. A rozé bor és a fröccs fogyasztásának divatossá válásával a fiatalok körében a bor egyre kedveltebb alkoholos ital lett. A régióban található számos borvidék és a hozzájuk kapcsolódó borgasztronómiai és borturisztikai rendezvény hatására közelebb kerültek a fiatalok a borok világához. Ebben a folyamatban jelentős szerepet töltenek be a Pannon borrégióban szép számmal működő, a borkultúrát és borfogyasztást népszerüsítő innovatív szervezetek, mint a borutak, a borturisztikai klaszter vagy a borrendek, valamint a Pécsi Tudományegyetem által szervezett borkultúra szabadegyetem, borszeminárium (GONDA RAFFAY 2015, MÁTÉ — SZABÓ 2011, OROSZI et al. 2015)

A következőkben a Pécsi Tudományegyetem hallgatóinak borvásárlási szokásait, valamint a borral kapcsolatos ismereteik forrását és bővítési hajlandóságát mutattuk be. Az egyetemnek, mint kultúra közvetítőnek, fontos szerepe van és lehet abban, hogy a fiatal felnőttek körében kialakuljon a kulturált és felelösségtudatos borfogyasztói magatartás, és ez az értelmiségi lét természetes részévé váljon. A hallgatók körében végzett borfogyasztási és borvásárlási szokás vizsgálattal nemcsak a fiatal felnőttek fogyasztási kultúrájáról kapunk helyzetképet, hanem arról is, hogy milyen területen van szükség ismeretek átadására és ehhez milyen megoldásokat érdemes fontolóra venni. A kérdőíves vizsgálat alapján megállapítható, hogy saját borfogyasztás esetén az ár (77,5\%), majd az íz, a minőség, a szőlő fajta és a borvidék a legfontosabb vásárlási döntést befolyásoló tényezők, míg ajándékozás esetén a legmeghatározóbb szempontok a minőség (82\%), az íz, az ár, a borvidék, az évjárat és a márka. Vagyis ajándékozáskor a bor minősége mérvadóbb, mint az ára, és fontosabbá válik a termőhely, a márka és az esztétikai tényezők szerepe. A válaszadók többsége hiper- és szupermarketekben, termelöknél és borszaküzletben vásárol bort.

A látszólag telítettnek tünő turisztikai piacon úgy tünik, hogy van egy olyan szegmens, amelynek a turizmusból származó részesedése eddig szinte elhanyagolható volt, annak ellenére, hogy e célcsoport aránya viszonylag nagy volt a világ népességéhez viszonyítva, — ők a fogyatékossággal élő emberek. Fizikai és egyéb akadályaik gyakran teszik szükségessé, hogy a turisztikai vállalkozások külön intézkedéseket hozzanak a szolgáltatásaik igénybevételére, azonban sok esetben csak szemléletváltásra lenne szükség. (RAFFAY — GONDA 2020a;2020b) A fogyatékosság, az akadálymentesség és az alkalmazkodás igen alapvető, egzisztenciális emberi jellemzők, így szükségessé válik az online platformok, szolgáltatások újratervezése és mindenki számára elérhetővé tétele. (FARKAS - PETYKÓ 2020a;2020b) A megkérdezettek a borral kapcsolatos információik jelentős részét barátoktól, ismerösöktől, családtól, rokonoktól, közösségi oldalról és az iskolától szerzik be. Tehát a fiatalok széles körü digitális tájékozottsága szükségessé teszi azt, hogy az információkat az általuk kedvelt csatornákon keresztül is eljuttassuk hozzájuk. Emellett a felsőoktatás, mint információ- és tudásbázis koncentráltan és hatékonyan tudja a borkultúrával kapcsolatos ismereteket átadni, amelyet a megkérdezettek többsége igényel is, hiszen úgy érzik, hogy nem növekedtek kellően az ismereteik a borról az elmúlt időszakban. A fiatalok többsége nyitott a boros programok és képzések iránt. A megkérdezettek $84 \%$-a szívesen részt venne borral kapcsolatos képzéseken. A hallgatók a képzésük során szívesen látogatna borral kapcsolatos szabadon választható tantárgyat pl. borszemináriumot. Érdekelné őket a borgasztronómiai, borszakértő képzés, gyakorlati képzés borkultúra szabadegyetem keretében, borturisztikai, szőlész-borász és sommelier képzés. A Pannon borrégió bormarketing stratégiája kiemelt célcsoportnak tekinti a fiatal felnőtteket, hiszen fogyasztási szokásaik még alakulóban vannak, azonban a legmarkánsabb vásárlóerejü generációnak számítanak. Másrészt hatékonyan elérhetőek (szervezett oktatás, média, internet, stb.), hiszen a fiatal felnőttek rendkívül fogékonyak a reklámokat és az újdonságokat illetően. A célcsoport borkultúra iránti érdeklődése folyamatosan növekszik, és életkoruk elörehaladtával körükben egyre divatosabbak a borhoz kötődö rendezvények, fesztiválok, borkóstolók, borvacsorák, a bortanfolyamok. 
Meghatározó szerepe van annak, hogy az egyetemi évek során a szakmai tanulmányaik mellett milyen egyéb kulturális ismerteket szereznek a hallgatók, sikerül-e felkelteni az érdeklődésüket a bor iránt, kialakul-e kötődés az egyetem vonzáskörzetének borvidékeihez. A Pécsi Tudományegyetem helyzeti előnyének köszönhetően számos kiemelkedő borászati vállalkozás, borúti szolgáltatás, innovatív látogatóközpont (pl. Garay Élménypince, Winespiration), bor- és gasztronómiai fesztivál került elérhető közelségbe a hallgatók számára. A pincészetekkel, borászati és borturisztikai szervezetekkel - például klaszter, borrendek, borút egyesületek - kialakított együttmüködéseknek köszönhetően az egyetem egyre változatosabb kínálatot tud biztosítani a hallgatók számára a borhoz kapcsolódó képzések terén: szőlész-borász mérnök, borturizmus szakirány turizmus-vendéglátás szakon, borjogi, valamint borturizmus és borgasztronómiai szakirányú továbbképzés és borkultúra szabadegyetem (ANGLER ET AL. 2015, GONDA RAFFAY 2015, GONDA - KOVÁCS 2014, MÁTÉ - SZABÓ 2011, OROSZI et al. 2015).

A Garay Élménypince Szekszárdon jó példaként szolgál az akadálymentes ismeretszerzés területén; föld alatti borélmény-körutat kínál a látás-, a hallássérültek, valamint a mozgáskorlátozottak, kerekesszékesek részére is, — így a teljes kiállítás végig járható számukra is. Ismeret nélkül nincs kulturált borfogyasztás, ismeretszerzésben az online borkóstolókkal egy további akadálymentes megoldást biztosítanak az élményekhez a járvány idején is.

\section{Irodalomjegyzék}

ALPÁR, L. - FARKAS, Z., GEÖNCZEÖL, A. - NEMES, R. - SZTAKOVICS, K. (2008): Közösségi Bormarketing Stratégia (Community Wine Marketing Strategy) 2009-2013. Manuscript, Magyar Bormarketing Kht., Budapest

ANGLER, K. (2020): Development Opportunities for people with disabilities in tourism. In: Gonda, T. - Schmidtchen, R. (Ed.) Opportunities and challenges of barrier-free tourism in Hungary. Results and recommendations of a scientific workshop during the conference "European Peer-Counselor Training in Accessible Tourism - Peer-AcT" on September 4, 2020 in Orfü (Hungary) Bonn, Németország: Bundesinstitut für Berufsbildung. 157 p. pp. 100-109.

ANGLER, K. - KRIZL, E. - MÁTÉ, A. - GONDA, T. (2015): Képzési igények a szőlészetborászat terén (Training demands in the field of viticulture and wine making). In: Tudásmenedzsment. 16 (2):86-96.

BORMARKETING MÜHELY NONPROFIT KFT. (2013): A magyar lakosság borfogyasztási szokásai (Wine consumption habits of the Hungarian population). In: Turizmus Bulletin. 15 (1.):5056.

DULA, B. - MÉSZÁROS, G. - ROHÁLY, G. (2012): A borfogyasztás kultúrája (The culture of the consumption of wine). Eszterházy Károly Föiskola, Eger

FARKAS, J. - PETYKÓ, CS. (2020a): Disability, accessibility, and mobility as basic existential characteristics. In: Gonda, T. - Schmidtchen, R. (Ed.) Opportunities and challenges of barrierfree tourism in Hungary. Results and recommendations of a scientific workshop during the conference "European Peer-Counselor Training in Accessible Tourism - Peer-AcT" on September 4, 2020 in Orfü (Hungary) Bonn, Németország: Bundesinstitut für Berufsbildung. 157 p. pp. 8999.

FARKAS, J. -PETYKÓ CS. (2020b): A fogyatékosság, az akadálymentesség és a mobilitás, mint egzisztenciális alaptulajdonság, TURISZTIKAI ÉS VIDÉKFEJLESZTÉSI TANULMÁNYOK 5 : 4 pp. 43-55., 13 p. (2020) DOI: 10.15170/TVT.2020

GONDA, T. - RAFFAY, Z. (2015): A tematikus utak szerepe a turizmus- és vidékfejlesztésben (The role of theme routes in touristic and rural developments). In: A falu 30 (1):49-58.

GONDA, T. (2014): A turisztikai klaszterfejlesztés régiós tapasztalatai a Dél- Dunántúlon (Experiences of tourism cluster development in South Transdanubia). In: Modern Geográfia (3):116. 
GONDA, T. - KOVÁCS, B. D. (2014): Wine producing areas and enological tourism in the Pannonian Wine Region. In: Vestnik Karagandinskogo Gosudarstvennogo Universiteta Seriya Ekonomika 75 (3):80-84.

GONDA, T. (2013): A Dél-Dunántúli turisztikai régió meghatározó turisztikai termékeinek az újra pozicionálása a turisztikai klaszterek segítségével (Repositioning of the dominant touristic products of the South Transdanubian touristic region with the assistance of tourism clusters). In: NFA Füzetek 3 (2):19-29.

GULD, ZS. - SLEZÁK-BARTOS, ZS. - NAGY, E. (2014). Libák százai lakolnak évtizedek óta: Márton nap, az újbor szentelés ünnepe (Hundreds of geese have died for this for decades: St. Martin's Day, the day of the consecration of the new wine). In: NFA Füzetek 3 (1): 94-97.

GULD, ZS. (2011): Borkedvelőknek miért éppen Szekszárd? (Why just Szekszárd for the lovers of wine?) In: NFA Füzetek 2 (2): 147-151.

HAJDU, I.-NÉ (ed. 2005): Borpiac (Wine market). Mezőgazda, Budapest

HAJDU, I.-NÉ (ed. 2004): Bormarketing (Wine marketing). Mezőgazda, Budapest

HOFMEISTER, TÓTH Á. - TOTTH, G. (2002): Az értékek szerepe a borválasztásban (The role of value in selecting wines). Manuscript, III. Magyarországi Bormarketing Konferencia előadás Sopron, 2002. december 5. http://www.bormarketingkonferencia.hu (Utolsó letöltés: 2003. december 1.)

MÁTÉ, A. (2020): Situation eines Komitatsmuseums und seine Möglichkeiten im barrierefreien Tourismus. In: Gonda, T. - Schmidtchen, R. (Ed.) Opportunities and challenges of barrier-free tourism in Hungary. Results and recommendations of a scientific workshop during the conference "European Peer-Counselor Training in Accessible Tourism - Peer-AcT" on September 4, 2020 in Orfü (Hungary) Bonn, Németország: Bundesinstitut für Berufsbildung. 157 p. pp. 53-72.

MÁTÉ, A. - OROSZI, V. - SLEZÁK-BARTOS, ZS. (2016): A fiatalok borfogyasztási szokásai (Wine consumption habits of the youth). In: BORÁSZATI FÜZETEK 26:(3) pp. 24-28.

MÁTÉ, A. - OROSZI, V. - SLEZÁK-BARTOS, ZS. (2016): A fiatalok borfogyasztási és borvásárlási szokásai (Wine consumption and wine purchasing habits of the youth) (2) In: BORÁSZATI FÜZETEK 26:(4) pp. 28-32.

MÁTÉ, A. - SZABÓ, G. - GONDA, T. - OROSZI, V. (2015): Borfogyasztási és borvásárlási trendek alakulása (The development of wine consumption and wine purchase trends). In: N. Horváth, B. (ed.): Tolna megye egyik húzóágazatának jövője: szőlészeti-borászati trendkutatás. PTE, Pécs

MÁTÉ, A. (2013): A bor, a turizmus és a városmarketing kapcsolatának néhány szempontja Szekszárd város példáján az ezredfordulótól 2010-ig (A few aspects of the relationship of wine, tourism and city marketing by the example of the city of Szekszárd - from the millennium to 2010). In: NFA Füzetek 2 (2): 91-100.

MÁTÉ, A. - SZABÓ, G. (2011): Bor- és gasztronómia terméktípus (Wine and gastronomy as touristic products). In: Michalkó, G. (ed.): Turisztikai terméktervezés és fejlesztés. PTE TTK Földrajzi Intézet - PTE IGYK, Pécs

MÁTÉ, A. (2007): A „Pannon borrégió” borútjainak összehasonlító értékelése (A comparative assessment of the wine routes of the Pannonian Wine Region). In: Modern Geográfia (4): 1-15. (Utolsó letöltés: 2010. október 12.)

http://www.moderngeografia.hu/tanulmanyok/magyar_turizmus/mate_andrea_2007_4.pdf

MTRt. - M.Á.S.T. (2006): A magyar lakosság étkezési és alkoholfogyasztási szokásai és Magyarország gasztronómiai imázsa 2005-ben (Eating and alcohol consumption habits of the Hungarian population and the gastronomic image of Hungary in 2005). In: Turizmus bulletin 10 (1):39-49.

OROSZI, V. GY. - GONDA, T. - GULD, ZS. - MÁTÉ, A. (2015): A borturizmus új trendjei Borturisztikai jó gyakorlatok a Pannon Borrégióban (New trends in enological tourism - good practises of enological tourism in the Pannonian Wine Region). In: N. Horváth, B. (ed.): Tolna megye egyik húzóágazatának jövője: szölészeti-borászati trendkutatás. PTE, Pécs 
OROSZI, V. GY. (2015): A Pannon borrégió jó gyakorlatai nemzetközi példák tükrében (Good practises of enological tourism in the Pannonian Wine Region - in the light of international examples). In: Oroszi, V. Gy. (ed.): Szölö, bor, turizmus: tanulmányok a szölészet, borászat és a borturizmus témaköréböl. Pécsi Tudományegyetem, Pécs

OSZOLI, Á. - SZABÓ, A. - MOLNÁR, E. - BOTOS, E. P. (2003): Borfogyasztási szokások Magyarországon (Wine consumption habits in Hungary). Manuscript, OSZKÖ Tanácsadó BT. és az FVM Szőlészeti és Borászati Kutatóintézete Kecskemét, Budapest

RAFFAY, Z. - GONDA, T. (2020a): Accessible tourism in some European countries - results of an empirical survey. In: Gonda, T. - Schmidtchen, R. (Ed.) Opportunities and challenges of barrier-free tourism in Hungary. Results and recommendations of a scientific workshop during the conference "European Peer-Counselor Training in Accessible Tourism - Peer-AcT" on September 4, 2020 in Orfü (Hungary) Bonn, Németország: Bundesinstitut für Berufsbildung. 157 p. pp. 23-52.

RAFFAY,Z._GONDA,T. (2020b) : Az akadálymentes turizmus innovatív jó gyakorlata. In: MODERN GEOGRÁFIA $2020: 4$ pp. 1-14. , 14 p. (2020)

SLEZÁK-BARTOS, ZS. - MÁTÉ, A. — GULD, ZS. (2020): Accessible Wine Consumption and Purchase Opportunities for Hungarian Young Consumers. In: Gonda, T. - Schmidtchen, R. (Ed.) Opportunities and challenges of barrier-free tourism in Hungary. Results and recommendations of a scientific workshop during the conference "European Peer-Counselor Training in Accessible Tourism - Peer-AcT" on September 4, 2020 in Orfü (Hungary) Bonn, Németország: Bundesinstitut für Berufsbildung. 157 p. pp. 73-88.

\section{Egyéb forrás:}

HEGYKÖZSÉGEK NEMZETI TANÁCSÁNAK honlapja: Bortemő területek és borvidékek Magyarországon. https://www.hnt.hu/szervezet/ Utolsó letöltés dátuma: 2021.február 18. 